\title{
Predictive Effect of Phubbing and Life Satisfaction on Depression Symptoms in Adults
}

\section{Yetişkinlerde Sosyotelizm (Phubbing) ve Yaşam Doyumunun Depresyon Belirtileri Üzerindeki Yordayıcı Etkisi}

\section{İzzet Parmaksız 1 iD}

1. Niğde Ömer Halisdemir Üniversitesi, Eğitim Fakültesi, Eğitim Bilimleri Bölümü, Rehberlik ve Psikolojik Danışma ABD, Niğde, Turkey

\begin{abstract}
Objective: Phubbing, defined as being busy on the phone by ignoring people, and life satisfaction, which appears as a person's attitude to life, also manifest themselves as variables that affect our mental health. The aim of this study was to determine the predictive effect of phubbing and life satisfaction on the depression symptoms level of the individual.

Method: The study group of the research consists of 756 adults (51.7\% Female, 48.3\% Male) living in Central Anatolia. The data of the study were collected using the Phubbing Scale, Beck Depression Scale, Life Satisfaction Scale and personal information form.

Results: A significant negative relationship between phubbing and life satisfaction, a significant negative relationship between life satisfaction and depression symptoms, and a significant positive relationship between phubbing and depression symptoms were found. According to the preliminary analysis, depression symptoms scores do not significantly differentiate according to gender; differentiates significantly according to marital status, educational level and perceived personality traits. According to the results of hierarchical regression analysis, life satisfaction and phubbing behavior were found to be medium-level predictors of depression symptoms.

Conclusion: Phubbing has been identified as a new descriptor for depression symptoms. Phubbing and life satisfaction are important predictors for depression symptoms.

Keywords: Depression symptoms, life satisfaction, phubbing

Öz
\end{abstract}

Amaç: İnsanları görmezden gelerek telefonuyla meşgul olma olarak tanımlanan sosyotelizm (phubbing) ve bireyin yaşama karşı tutumu olarak beliren yaşam doyumu da ruh sağlığımıı etkileyen değişkenler olarak kendini göstermektedir. Bu araştırmada sosyotelizm ve yaşam doyumunun bireyin depresyon belirti düzeyi üzerindeki yordayıcı etkisini saptamak amaçlanmıştır.

Yöntem: Araştırmanın çalışma grubu Orta Anadolu'da yaşayan 756 (\%51.7 Kadın, \%48.3 Erkek] yetişkin bireyden oluşmaktadır. Araştırmanın verileri Sosyotelizm Ölçeği, Beck Depresyon Ölçeği, Yaşam Doyumu Ölçeği ve kişisel bilgi formu kullanılarak toplanmıştır.

Bulgular: Sosyotelizm ile yaşam doyumu arasında anlamlı negatif bir ilişki, yaşam doyumu ile depresyon belirtileri arasında anlamlı negatif bir ilişki ve sosyotelizm ile depresyon belirtileri arasında anlamlı pozitif bir ilişki saptanmışıır. Yapılan ön analize göre depresyon belirti puanları cinsiyete göre anlamlı farklılaştırmazken; medeni durum, eğitim düzeyi ve algılanan kişilik özelliklerine göre anlamlı farkllaş̧ırmaktadır. Hiyerarşik regresyon analizi sonuçlarına göre yaşam doyumu ve sosyotelizm davranışının depresyon belirtilerinin orta düzeyde yordayıcıları olduğu bulunmuștur.

Sonuç: Sosyotelizm depresyon belirtileri için yeni bir yordayıcı olarak belirlenmiştir. Sosyotelizm ve yaşam doyumu depresyon belirtileri için önemli yordayıcılardır.

Anahtar kelimeler: Sosyotelizm, phubbing, depresyon belirtileri, yaşam doyumu 


\section{Introduction}

Depression is one of the most important mental problems today and depressive tendencies are increasing day by day. According to the psychoanalytic approach, the cause of depression is the experiences of infancy and early childhood (1). According to the cognitive theory, depression is related to certain cognitive distortions in individuals prone to depressive mood. According to the behavioral approach, learned helplessness is at the forefront. It is stated that depression is the wrong learning (2). Depression is when an individual feels sad and stagnates while thinking, talking, and performing motor movements. In addition, it manifests itself as a mental problem dominated by a negative perspective, along with a decrease in self-esteem, inadequacy, and weakness (3). When we evaluate it in terms of the cognitive model, it is seen that the individual misinterprets their lives. This misinterpretation reveals a pessimistic situation regarding the person himself, his present life and future. Along with the beliefs of inadequacy, the person has thoughts that his life is covered with obstacles, that he will have more problems in the future and that everything will be unsolved (4). In terms of the recovery process, while there are sufficient treatment options for depression, a significant portion of individuals cannot provide recovery (5). In addition, low socio-economic and educational status, irregular or broken family, genetic, neurochemical substances, hormones and psychological factors can be risk factors for depression (6). Therefore, it is necessary to investigate modifiable risk factors and effective methods of preventing depression.

Recently, one of the important causes of depression is the use of technology. Phubbing behavior, which has become widespread with the use of mobile phones today, has become one of the important triggers of depression by affecting mental health. Because phubbing is also related to mental health, indirect and direct positive relationships have been found between phubbing and depression in various age groups ( 7 , 8). Davey et al. (9) reported that phubbers have high levels of depression. In addition, it has been observed that phubbers have low psychological well-being and have high anxiety and depression scores (10). Wang et al. (7) concluded that phubbing is a major risk factor for depression. González-Rivera et al. (11) concluded that individuals with high phubbing behaviors have higher levels of stress, anxiety, and depression, and lower levels of psychological well-being. Thus a study about the risk factors of phubbing found a positive and strong correlation between phubbing and neurotic behavior. Because neurotic behaviors are one of the most important descriptors of depression (12). Ergun et al. (13), David and Roberts (14), González-Rivera et al. (11), Garrido and Delgado (10), Roberts and David (8) have found that phubbing can trigger depression. These results can be interpreted as phubbing tendency increases the level of depression symptoms. As it is seen, it can be said that phubbing is a variable associated with depression symptoms.

In today's world, technology always exists in our life with its positive and negative effects, and cannot be given up. Phones, which are important gadgets of life and used to communicate with people who are not physically close, have almost become a part of social life. Just like our individual belongings, almost every individual has his/her own phone. However, more than our necessary preoccupation with these devices that we need to make life easier can have negative effects on our social relationships. While technology affects our lives in every aspect, our mental health is negatively affected by the wrong behaviors caused by technology. The negative effects of smartphones used by millions of people all over the world (15) have increased too much to ignore. One of the most common negative effects of technology is phubbing, a behavioral problem. It is seen that people use their smart phones by ignoring the people they are physically in the same environment. This behavior is called "phubbing", which has become a common phenomenon in communication activities $(12,16)$. "Phubbing" is a concept created by the combination of the words phone and snubbing. This concept was added to the Macquarie Dictionary in 2013 and started to be used. For this reason, researches on the concept of phubbing started after 2013 (17). It is seen that the studies done in the world in Google Academic have increased especially as of 2020. Considering the literature in our country, it has been observed that there are studies such as the fear of missing out on developments and neuroticism (18), phubbing tendencies of new generation people (19), boredom (20), personality and 
life satisfaction (21), psychological variables (13), relationship satisfaction (22), game, internet, smart phone, and social media addiction (23), effects of phubbing in school (24) causes of phubbing and its effects on social life (25). In addition to these studies, it has been observing that there are also review articles (26-28).

In addition, studies on phubbing have shown that delayed responses, the sedentary body, and the lack of eye contact in phubbing situations lead to apathy and desire not to continue speaking (29). This behavior negatively affects the initiation and continuation of interpersonal relationships, the quality of relationships, emotional ties between family members, as well as the ability of children, adolescents, and young people to communicate with others $(7,11)$. Phubbing is also a type of social exclusion behavior (30). Phubbing behavior negatively affects the social development of the individual and prevents the individual's communication and interaction in social environments (31). Phubbing, which emerged as a form of social exclusion connected to mobile phones, may lead people exposed to this behavior to experience more negative emotions and less positive emotions than those who are not exposed $(32,33)$. Phubbing behavior negatively affects relationship satisfaction as well as personal well-being $(8,34,35)$. In addition, if a person uses his/her phone during the current social interaction can cause the other person to use his/her own phone in reaction. As for some people don't even remember how busy they were on the phone (36). Studies on the effects of phubbing show that people may create negative reactions, such as perceiving their interactions with a lower quality, and most people are angry with this behavior (37) and are less satisfied with their interactions (34). Research results on Phubbing report that this type of addiction has a negative impact on adolescents, family members, social relationships, and couple relationships $(12,38,39$, 40). It can be said that this addictive behavior, which has significant effects on the quality of social activities and interpersonal communication $(42,43)$ may also have effects on mental health and trigger some psychological disorders. Roberts and David (8) found that phubbing negatively affects the well-being of the person and is associated with depressive feelings. Davey et al. (9) also reported that individuals exhibiting phubbing behaviors have high levels of depression. Depression is also a mental condition that directly affects an individual's life satisfaction. These results also confirm the relationship of phubbing tendency with depression symptoms and life satisfaction.

Life satisfaction refers to an attitude consisting of whether the individual enjoys his / her current life and his / her evaluations regarding the quality of life $(44,45)$. Individuals with high life satisfaction are those who enjoy life more, feel positive emotions more, have higher self-esteem, and have an optimistic perspective on life (46). Low life satisfaction is an important predictor of probable psychological disorders (47). One of the most serious ailments that we may encounter is depression. Some studies have reported a negative relationship between life satisfaction and depression. (48-51). As can be understood from the results, increasing life satisfaction decreases depression (52). Al-Saggaf et al. (38) states that the life satisfaction, relationship quality and relationship satisfaction levels of phubbers are negatively affected. It has been determined that phubbers are less satisfied with their lives and feel more lonely than other individuals (39). In addition phubbing has emerged as a technology-related behavioral problem, and considering the literature, one of the causes of behavioral disorders is impulsivity. Impulsivity can also trigger some psychiatric disorders such as depression (53). However, depressive tendency can reduce the life satisfaction of the individual. In addition, impulsivity is associated with a decrease in positive affect, increased level of depression, and prolonged smartphone use (54). As it is understood, these 3 variables are related depending on the impulsive tendencies of the individuals. This study is important in terms of making important contributions to the literature in our country, that only a limited number of studies have been conducted on phubbing. Since phubbing is a new concept, its theoretical background is not sufficient. The concept is expressed together with technology addictions such as smart phone, internet, game, and application addiction. It has a conceptual definition, but it has not have a clear category with its behavioral dimension yet. Therefore, the data obtained from this study will make important contributions to the understanding of the concept of phubbing with its different dimensions. Because in many aspects, this research is a study in which original data can be obtained. Because when the contents of the studies were examined, it was seen that there was no study that examined the relationship of phubbing with life 
satisfaction and investigated the predictive effect of phubbing and life satisfaction on depression symptoms. This research, on the other hand, is a highly representative study as it has a sample of a wide age range of adults, and it is an original study in terms of its subject. For this purpose whether sex, marital status, education level and perceived personality traits differentiate depression symptom scores, and the predictive effect of life satisfaction and phubbing on depression symptoms were examined.

\section{Method}

This study is a relational screening model to examine the relationships between phubbing, depression symptoms and life satisfaction. Relational screening model among the general screening model types; It is a research model that aims to determine the existence and degree of co-change between two or more variables (55).

\section{Sample}

This study was carried out with the participation of 756 volunteers living in Central Anatolia [Female: 391 (51.7\%), Male: $365(48.3 \%)]$. The ages of the participants ranged from 25 to 68 (Mean $\pm s d=34.51 \pm$ 8.43). 454 of the participants have been married (60.1\%), 302 have been single (39.9\%). The simple random sampling method was used in the study and the volunteering of the participants was taken as a basis.

\section{Procedure}

The study was approved by the Ethics Committee of Niğde Ömer Halisdemir University (11.09.2020 / 86837521-050.99-E.40198). Before the application, the participants were informed in detail about the study by providing a voluntary consent form. Afterwards, phubbing scale, depression scale, life satisfaction scale and personal information form were applied. It was aimed to prevent social acceptance error by expressing to the participants that their responses to the scales would be kept confidential. The application of the scales took approximately 20 minutes.

\section{Measures}

\section{Personal Information Form}

The personal information form created by the researcher consists of information such as the age, gender, marital status, educational level and perceived personality traits of the participants. Perceived personality traits were added to the personal information form according to Benet-Martínez and John (56).

\section{Phubbing Scale}

The scale was developed by Karadağ et al. (25). It is a scale developed to measure individuals' phubbing tendency. An exploratory factor analysis was performed by using a principal axis factor analysis with an Oblimin rotation. Correspondingly, the items with factor loadings less than 1.401 for all the factors or a difference less than 1.10 l for at least two factors were eliminated. Cronbach Alpha reliability coefficients were calculated for each factor. As a result of the principal component analysis, a two (2)-factor structure, explaining $56.19 \%$ of the variance was proposed (KMO $=.87$, Bartlett's test $=p<.01$ ). As the result of the exploratory factor analysis performed by using the Oblimin principal axis rotation, 10 items were loaded over I.40I in only one factor.

The scale consists of 10 items and 2 factors are as follows: (i) Communication disorder ( 5 items; $\alpha=.87$ ) and (ii) Phone passion (5 items; $\alpha=.85$ ). It is a 5-point Likert type measuring instrument with an answer scale between never (1) and always (5). The lowest and highest score to be obtained from the scale were ranged from 10 to 50. A score of 40 or more from the scale expresses individuals' phubbing addiction. In this study, the internal consistency coefficient of the scale was calculated with the Cronbach's Alpha method and was calculated as .83. 


\section{Life Satisfaction Scale}

The original of the scale was developed by Diener, Emmons, Larsen, and Griffin. The adaptation study of the scale into Turkish was done by Dağlı and Baysal (57). In statistical analysis, a high level of positive and significant relationship was found between the English and Turkish of the scale $(r=.92 ; p=0.00)$. Exploratory factor analysis and confirmatory factor analysis were conducted to examine the construct validity of the scale. The $\left(x_{2} / \mathrm{df}\right)$ rate calculated with CFA is 1.17. This value reveals that the proposed factor model is compatible with the data. According to the results of the factor analysis, it was determined that the Life Satisfaction Scale has a single-factor structure as in its original form and consists of 5 items, as in the original scale. The Cronbach Alpha internal consistency coefficient of the scale is .88. Test-retest reliability is .97. According to these results, the scale has a high level of internal consistency (57). In this study, the internal consistency coefficient of the scale was calculated with the Cronbach's Alpha method and was calculated as .81.

\section{Beck Depression Scale}

The scale, adapted to Turkish by Hisli (58), consists of 21 items. The scores obtained from the scale were ranged from 0 to 63 . High scores indicate a high level of depression. The internal reliability coefficient of the Turkish form of the scale was .80, and the split-half reliability was .74. According to the data obtained from this study, the internal consistency coefficient of the scale was calculated as .83.

\section{Statistical Analysis}

Within the scope of this research, the relationship between variables was examined and firstly the homogeneity of the data was tested. The sample has a normal distribution. The value for skewness ranges from -.19 to .89 for all variables; kurtosis value is in the range from -.45 to .37 for all variables. The skewness and kurtosis coefficients of the scores being close to \pm 1 limits can be interpreted as the scores do not deviate excessively from normal (59). Pearson's correlation coefficient was used to determine the relationships between life satisfaction, phubbing and depression symptoms. T-test was used to determine whether sex and marital status significantly differentiated depression symptom scores. one-way analysis of variance (ANOVA) was used to determine whether educational level and perceived personality traits significantly differentiated depression symptom scores. Hierarchical regression analysis was performed to determine the predictive effect of phubbing and life satisfaction on the depression symptoms. In hierarchical regression analysis, the researcher enters the predictive variables in a specific order determined by theoretical or empirical evaluations. Thus, by calculating the change in corrected $\mathrm{R} 2$ in each step of the hierarchical regression analysis, the variance increase is observed in the regression model after each variable or group of variables (60). An outlier with a Mahalanobis distance value was not found. The Durbin-Watson value used to test autocorrelation is 1.76. The data were analyzed in SPSS 22 program.

Table 1. Participants' sociodemographic characteristics

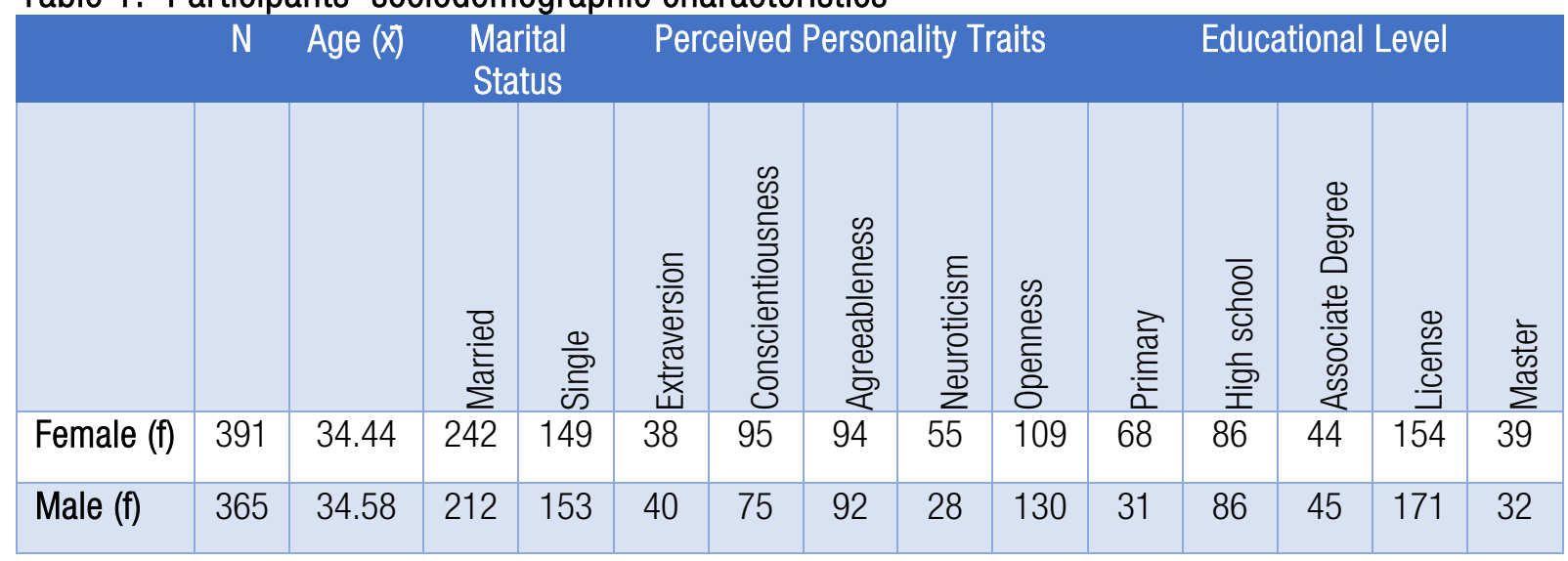




\section{Results}

As seen in Table 2, the depression symptoms scores of the participants do not differ significantly according to the variable of gender $\left(t_{(2-754)}=-.98, p>.05\right)$; On the other hand, it was found that there was a significant difference according to the marital status variable $\left(t_{(2-754)}=-3.25, p<.05\right)$. Considering at the results, it was seen that the depression symptoms scores of married individuals were lower.

Table 2. Differentiation of depression symptoms scores by gender and marital status

\begin{tabular}{|l|c|c|c|c|}
\hline & \multicolumn{2}{|c}{ Variable } & $t_{756)}$ & $p$ \\
\hline mean \pm SD & Female $(n=391)$ & Male $(n=365)$ & -.98 & .33 \\
\hline Depression scores & $14.03 \pm 8.07$ & $13.44 \pm 8.68$ & & \\
\hline & Married $(n=454)$ & Single $(n=302)$ & -3.25 & .00 \\
\hline Depression scores & $12.94 \pm 8.11$ & $14.95 \pm 8.61$ & & \\
\hline
\end{tabular}

Tablo 3. Differentiation of depression symptoms scores by educational level and perceived personality traits

\begin{tabular}{|c|c|c|c|c|c|c|}
\hline \multicolumn{2}{|c|}{ 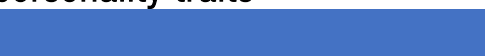 } & $\mathrm{N}$ & Mean & SD & \multirow{2}{*}{$\begin{array}{c}F \\
7.85\end{array}$} & \multirow{2}{*}{$\begin{array}{c}p \\
0.00\end{array}$} \\
\hline \multirow{5}{*}{$\begin{array}{l}\text { Educational } \\
\text { Level }\end{array}$} & Primary & 99 & 14.95 & 8.04 & & \\
\hline & High school & 172 & 15.64 & 9.17 & \multirow{4}{*}{7.85} & \\
\hline & Associate Degree & 89 & 15.19 & 8.56 & & \\
\hline & License & 325 & 12.73 & 7.73 & & \\
\hline & Master & 71 & 10.29 & 7.78 & & \\
\hline \multirow{5}{*}{$\begin{array}{l}\text { Perceived } \\
\text { Personality } \\
\text { Traits }\end{array}$} & Extraversion & 78 & 12.60 & 8.08 & \multirow[t]{5}{*}{7.72} & \multirow[t]{5}{*}{0.00} \\
\hline & Conscientiousness & 170 & 13.77 & 8.41 & & \\
\hline & Agreeableness & 186 & 12.96 & 7.82 & & \\
\hline & Neuroticism & 83 & 18.37 & 9.22 & & \\
\hline & Openness & 239 & 13.11 & 8.07 & & \\
\hline
\end{tabular}

${ }^{*} \mathrm{p}<.001$

One-way analysis of variance (ANOVA) was conducted to determine whether educational level and perceived personality traits significantly differentiated depression symptoms scores. When table 3 was examined, it was seen that educational level and perceived personality traits significantly differentiate depression symptoms scores. According to the tukey test, it can be stated that individuals who stated that they had anxious personality traits were more depressive than those who had other personality traits. In addition, the decrease in the education level increases the depression symptoms average.

Table 4. Mean, standard deviation and correlations of scales

\begin{tabular}{|c|c|c|c|c|c|c|}
\hline Variables & Mean $\pm S D$ & $P$ & DS & LS & Skewness & Kurtosis \\
\hline Phubbing & $26.19 \pm 7.52$ & 1.00 & & & -.19 & -.35 \\
\hline Depression Symptoms & $13.74 \pm 8.37$ & $22^{*}$ & 1.00 & & .07 & -.45 \\
\hline Life Satisfaction & $15.96 \pm 4.24$ & $-.15^{\star}$ & $-.42^{\star}$ & 1.00 & .89 & .37 \\
\hline
\end{tabular}

${ }^{*} \mathrm{p}<.01 \quad \mathrm{P}$ :Phubbing, DS:Depression Symptoms , LS: Life Satisfaction

When the correlation analysis results were examined in Table 4; a medium-level positive relationship between phubbing and depression symptoms; a medium-level negative relationship between phubbing and life satisfaction; It was seen that there was a strong negative relationship between depression symptoms and life satisfaction.

Since marital status, educational level, and perceived personality traits significantly differentiate depression symptoms scores, it was defined as a dummy variable. Since the effect level of demographic variables without other variables is curious, first of all, the predictive effect of these variables was examined. Then, the analysis continued according to the relationship level size. The results of the hierarchical regression analysis were performed to determine whether the phubbing and life satisfaction scores of the participants predict depression symptoms scores which have been given in Table 5 . 
Table 5. Hierarchical regression analysis

\begin{tabular}{|c|c|c|c|c|c|c|}
\hline \multicolumn{2}{|l|}{$\begin{array}{l}\text { Dependent } \\
\text { Variable }\end{array}$} & Independent Variable & $\mathrm{R}^{2}$ & $F$ & $\beta$ & $t$ \\
\hline $\begin{array}{l}\text { Depression } \\
\text { Symptoms }\end{array}$ & Step 1 & $\begin{array}{l}\text { Marital Status } \\
\text { Educational Level } \\
\text { Perceived Personality Traits }\end{array}$ & .10 & $26.60^{*}$ & $\begin{array}{l}-.176 \\
-.229 \\
-.174\end{array}$ & $\begin{array}{l}-4.82^{*} \\
-6.27^{*} \\
-4.98^{\star}\end{array}$ \\
\hline & Step 2 & $\begin{array}{l}\text { Marital Status } \\
\text { Educational Level } \\
\text { Perceived Personality Traits } \\
\text { Life Satisfaction }\end{array}$ & .22 & $53.57^{\star}$ & $\begin{array}{l}-.093 \\
-.180 \\
-.123 \\
-.369\end{array}$ & $\begin{array}{l}-2.68^{\star} \\
-5.26^{\star \star} \\
-3.75^{\star} \\
-11.03^{\star}\end{array}$ \\
\hline & Step 3 & $\begin{array}{l}\text { Marital Status } \\
\text { Educational Level } \\
\text { Perceived Personality Traits } \\
\text { Life Satisfaction } \\
\text { Phubbing }\end{array}$ & .25 & $48.60^{*}$ & $\begin{array}{l}-.074 \\
-.185 \\
-.108 \\
-.351 \\
.155\end{array}$ & $\begin{array}{l}-2.14^{\star \star} \\
-5.482^{\star} \\
-3.32^{\star \star} \\
-10.57^{\star} \\
4.75^{\star}\end{array}$ \\
\hline
\end{tabular}

${ }^{\star} \mathrm{p}<.001,{ }^{\star *} \mathrm{p}<.01,{ }^{\star * \star} \mathrm{p}<.05$

When Table 5 was examined, according to the results of hierarchical regression analysis, the predictive effect of dummy variables was $10 \%$. With the inclusion of life satisfaction in the analysis in the second stage, the predictive effect increased to $22 \%$. With the addition of phubbing behavior in the third stage to the analysis, it was seen that the total predictive effect of all variables increased to $25 \%$.

\section{Discussion}

In this study, the predictive effect of life satisfaction and phubbing on depression symptoms was examined, it was determined that life satisfaction and phubbing are predictors of depression symptoms. In this study, parallel with the findings of Donnelly et al. (61), Ören and Gençdoğan, (62), Yavuzer and Karatas (63) it was determined that gender didn't have a significant effect on depression. On the other hand, İskender et al. (64) found that gender significantly differentiates depression scores. According to the findings of this study, it was determined that marital status, educational level, and perceived personality traits significantly differentiated depression symptoms scores. Demirel (65) found that marital status had no significant effect on depression. On the other hand, in parallel with the findings of this study, Williams (66) and Simon (67) found that the depression levels of married individuals were lower, and their wellbeing levels were higher than those of single ones. In terms of educational level, a decrease in educational level increases depression symptoms scores. This result parallels on literature $(68,69,70)$. The findings of this study showed that the perceived personality traits significantly differentiated the depression symptoms scores. In addition, it can be stated that personality traits are related to the onset and cause of depression in different ways and directly affect the level of depression (71). In the studies of Çayırlı (72) and Bulut (73), it was also stated that personality traits were related to depression.

In this study, a significant relationship was found between phubbing and life satisfaction. However, in some studies, it was found that there was no significant relationship between life satisfaction and phubbing behavior and that life satisfaction did not predict phubbing. However, in the same study, it was found that exposure to phubbing and life satisfaction was negative significant relationship and exposure to phubbing predicted life satisfaction (13). In addition to phubbing, exposure to this behavior also feeds negative emotions in individuals. In addition, by doing phubbing, individuals become lonely and negatively affect the mental health of others. Thus, as phubbing increases, communication quality and life satisfaction decrease significantly (32). This situation turns into a negative situation for mental health.

As it is seen, our various qualities, behavioral characteristics and perceptions can affect our emotional life. The reasons for the emergence of depression symptoms are also affected by new situations with the changing time, and the innovations that come into our lives can manifest themselves positively or negatively as affecting depression symptoms. Phubbing, which has emerged with the widespread use of smartphones, has also turned into one of the most important descriptors of depression symptoms. Ergun 
et al. (13), David and Roberts (14), González-Rivera et al. (11), Garrido and Delgado (10), Roberts and David (8) have found that phubbing can trigger depression. These results can be interpreted as phubbing tendency increases the level of depression symptoms. According to the literature, the most effective factor in phubbing addiction is the use of smartphones (25). The way to reduce phubbing, which is one of the important triggers of depression symptoms, is possible with the conscious use of smartphones. As a mediator of the relationship between mobile phone addiction and depression, it has been found that increased phubbing is associated with the emergence of depressive moods in individuals (74). Based on the current findings, we can minimize depression symptoms by preventing phubbing with communication that supports individuals' empathic tendencies. Also, Wang et al. (7) states that couples making phubbing to each other may pose a risk for depression and similar emotional experiences. In different relational experiences, they may unwittingly reflect the feeling that individuals are not valuable to each other. A small awareness that can be created especially for sensitive individuals can be effective in seeing the negative consequences of phubbing behavior. Our findings are also in line with studies showing that phubbing is associated with stress, which is the trigger of depression and depression, in both social and partner relationships $(8,75)$. All these results support the validity of the research data.

The findings of this study show that life satisfaction is a predictor of depression symptoms. There is a strong relationship between life satisfaction and depression $(13,76)$. Studies show that life satisfaction is one of the most important determinants of mental health $(47,77,78)$. Mahmoud et al. (50) found that individuals with low life satisfaction who do not enjoy their lives experience depression, anxiety, and stress. As people's life satisfaction decreases, they become more vulnerable to depressive symptoms. Therefore, increased life satisfaction has an influence on reducing the depression symptoms observed in individuals (79). As can be understood from these results, life satisfaction can be increased by looking optimistically and seeing the positive and advantageous side of events. Thus, if wrong habits such as phubbing are brought under control, depression and other problems can be easily overcome. Thus, the unwanted effects of all possible negativities can be reduced.

In the study, phubbing seems to be a concept that is especially emphasized. Considering the literature in our country, it has been observed that there are studies such as the fear of missing out on developments and neuroticism (18), phubbing tendencies of new generation people (19), boredom (20), personality and life satisfaction (21), psychological variables (13), relationship satisfaction (22), game, internet, smart phone, and social media addiction (23), effects of phubbing in school (24) causes of phubbing and its effects on social life (25). The lack of a study sample in our country dealing with depression symptoms, life satisfaction and phubbing increases the importance of the study. In this respect, it will make original contributions to the literature.

These research findings are limited to the data obtained from measurement tools. One of the limitations of the study is the use of a small number of demographic variables. In addition, since it is studied in a very common problem area, a larger sample can be used to generalize. However, not including adolescents in the study restricted the possibility of making comparisons.

Looking at the results of the study, it was found that phubbing and life satisfaction were significant predictors of depression symptoms. Phubbing behavior, which negatively affects the quality of social activities and interpersonal communication of individuals $(42,43)$, is becoming more common with increasing technological developments. Therefore, more technology literacy training and awareness-raising studies are needed (80). Smartphone addiction is one of the main causes of phubbing $(25,81)$. Therefore, educational studies for both children and adults can be organized for the correct use of smartphones and similar technologies. Thus, the adverse effects of this risk factor can be prevented. The risk of experiencing depression and similar mental health problems may also be reduced. In addition, when the literature was examined, it was seen that there are many factors affecting the life satisfaction of individuals. Life satisfaction can vary from individual to individual and from society to society (82). For this reason, it is not correct to generalize, and psycho-educational studies or seminars can be organized for the result obtained by determining the factors affecting the life satisfaction of the studied sample. In future 


\section{Bağımlılık Dergisi - Journal of Dependence}

studies, comparisons can be made by conducting this study with different socio-economic levels and age groups.

\section{References}

1. Taylor D, Richardson P. The psychoanalytic/psychodynamic approach to depressive disorders. In: Gabbard GO, Beck JS, Holmes J. (editors.). Oxford Textbook of Psychotherapy Oxford: Oxford University Press, 2005: 127136

2. Yüksel N. Ruhsal Hastalıklar 4. Baskı, Ankara: MN Medikal \& Nobel, 2014.

3. Beck AT, Alford BA. Depression: Causes and treatment. 8. Edition, Philadelphia: University of Pennsylvania Press, 2009.

4. Sharf RS. Psikoterapi ve psikolojik danışma kuramları Voltan-Acar N, (çeviri editörü). 5. Baskı, Ankara: Nobel Yayıncllik, 2018.

5. Mathers, CD, Loncar D. Projections of global mortality and burden of disease from 2002 to 2030. PLoS Med 2006; 3(11): e442.

6. Türen E. Prenatal anne-bebek bağlanmasında maternal oksitosin, kortizol ve prolaktin düzeylerinin etkisi ve annenin depresyon, anksiyete ve stres düzeylerinin ilişkisi (Uzmanlık Tezi). Necmettin Erbakan Üniversitesi Meram Tıp Fakültesi Kadın Hastalıkları ve Doğum Anabilim Dalı, Konya, 2014.

7. Wang $X$, Xie X, Wang $Y$, et al. Partner phubbing and depression among married Chinese adults: The roles of relationship satisfaction and relationship length. Pers Individ Dif 2017; 110: 12-17.

8. Roberts JA, David ME. My life has become a major distraction from my cell phone: Partner phubbing and relationship satisfaction among romantic partners. Comput Human Behav 2016; 54: 34-41.

9. Davey S, Davey A, Raghav SK, et al. Predictors and consequences of "Phubbing" among adolescents and youth in India: An impact evaluation study. J Fam Community Med 2018; 25: 35-42.

10. Garrido EC, Delgado SC. Phubbing. Conectados a la red y desconectados de la realidad. Un análisis en relación al bienestar psicológico. Pixel-Bit. Revista de Medios y Educación 2017; 50: 173-185.

11. González-Rivera J, Segura-Abreu L, Urbistondo-Rodríguez V. Phubbing in romantic relationships: Cell phone use, couple satisfaction, psychological well-being and mental health. Interacciones 2018; 4(2): 81-91.

12. Guazzini A, Duradoni M, Capelli A, Meringolo P. An explorative model to assess individuals' phubbing risk. Future Internet 2019; 11(1): 21.

13. Ergün N, Göksu I, Sakız H. Effects of phubbing: Relationships with psychodemographic variables. Psychol Rep 2020; 123(5): 1578-1613.

14. David ME, Roberts JA. Developing and testing a scale designed to measure perceived phubbing. Int J Environ Res Public Health 2020; 17(21): 8152.

15. Mieczakowski A, Goldhaber T, Clarkson P. Culture, Communication and Change: Summary of an Investigation of the Use and Impact of Modern Media and Technology in Our Lives; Technical Report. Cambridge Engineering Design Centre, 2011.

16. Chotpitayasunondh V, Douglas KM. How "phubbing" becomes the norm: The antecedents and consequences of snubbing via smartphone. Comput Human Behav 2016; 63: 9-18.

17. Macquarie Dictionary. Available from: https://www.macmillandictionary.com/buzzword/entries/phubbing.html. Accessed: 30.05.2020.

18. Balta S, Emirtekin E, Kircaburun K, Griffiths MD. Neuroticism, trait fear of missing out, and phubbing: The mediating role of state fear of missing out and problematic instagram use. Int J Ment Health Addict 2020; 18: 628-639.

19. Ünalan D, Yıldıım O. Dijital yerlilerin sosyotelizm (phubbing) eğilimlerinin değerlendirilmesi. Gümüşhane Üniversitesi Iletişim Fakültesi Elektronik Dergisi 2020; 8(1): 276-297.

20. Yam FC, Kumcağı H. Adaptation of general phubbing scale to Turkish culture and investigation of phubbing levels of university students in terms of various variables. Addicta: The Turkish Journal on Addictions 2020; $7(1): 48-60$.

21. Çikrikci Ö, Griffiths, MD, Erzen E. Testing the mediating role of phubbing in the relationship between the big five personality traits and satisfaction with life. Int J Ment Health Addict 2019; doi: 10.1007/s11469-019-00115-z.

22. Çizmeci E. Disconnected, though satisfied: Phubbing behavior and relationship satisfaction. The Turkish Online Journal of Design, Art and Communication 2017; 7(2): 364-375.

23. Karadağ E, Tosuntaş ŞB, Erzen $E$, et al. Sanal dünyanın kronolojik bağımlılı̆ı: Sosyotelizm (phubbing). Addicta: The Turkish Journal on Addiction 2016; 3(2): 223-269. 
24. Ugur NG, Koc T. Time for digital detox: Misuse of mobile technology and phubbing. Procedia Soc Behav Sci 2015; 195: 1022-1031.

25. Karadağ $E$, Tosuntaş ŞB, Erzen $E$, et al. Determinants of phubbing, which is the sum of many virtual addictions: A structural equation model. J Behav Addict 2015; 4(2): 60-74.

26. Parmaksız I. Phubbing (Sosyotelizm). İşcan A (editör.) Eğitim Bilimlerinde Örnek Araştırmalar. 1. Baskı, Ankara: Nobel Yayınları, 2018: 601-617.

27. Parmaksız İ. İletişimde ve ilişkilerde phubbing. Türkiye Sosyal Araştırmalar Dergisi 2020; 24(2): 359-372.

28. Yam FC, IIlhan T. Modern çağın bütünsel teknolojik bağımlılığl: Phubbing ve dinamikleri. Psikiyatride Güncel Yaklaşımlar 2020; 12(1): 1-15.

29. Aagaard J. Mobile devices, interaction, and distraction: a qualitative exploration of absent presence. Al Soc 2016; 31: 223-231.

30. Roberts JA, David ME. Put down your phone and listen to me: How boss phubbing undermines the psychological conditions necessary for employee engagement. Comput Human Behav 2017; 75: 206-217.

31. Luk TT, Wang MP, Shen C, et al. Short version of the Smartphone Addiction Scale in Chinese adults: Psychometric properties, sociodemographic, and health behavioral correlates. J Behav Addict 2018; 7(4): 1157-1165.

32. Chotpitayasunondh V, Douglas KM. The effects of "phubbing" on social interaction. J Appl Soc Psychol 2018; 48(6): 304-316.

33. Hales $A H$, Dvir $M$, Wesselmann $E D$, et al. Cell phone induced ostracism threatens fundamental needs. J Soc Psychol 2018; 158(4): 460-473.

34. Vanden Abeele MMP, Antheunis ML, Schouten AP. The effect of mobile messaging during a conversation on impression formation and interaction quality. Comput Human Behav 2016; 62: 562-569.

35. Vallespín M, Molinillo S, Muñoz-Leiva F. Segmentation and explanation of smartphone use for travel planning based on socio-demographic and behavioral variables. Industrial Management and Data Systems 2017; 117(3): 605-619.

36. Vanden Abeele MMP, Hendrickso AT, Pollmann MMH, Ling R. Phubbing behavior in conversations and its relation to perceived conversation intimacy and distraction: An exploratory observation study. Comput Human Behav 2019; 100: 35-47.

37. Ranie L, Zickuhr K. Americans' Views on Mobile Etiquette. Washington DC: Pew Research Center, 2015.

38. Al-Saggaf $Y$, MacCulloch R, Wiener K. Trait boredom is a predictor of phubbing frequency. J Technol Behav Sci 2019; 4: 245-252.

39. Błachnio A, Przepiorka A. Be aware! If you start using Facebook problematically you will feel lonely: Phubbing, Ioneliness, self-esteem, and Facebook intrusion. A cross-sectional study. Soc Sci Comput Rev 2019; 37(2): 270-278.

40. Barrios-Borjas DA, Bejar-Ramos VA, Cauchos-Mora VS. Excessive use of smartphones/cell phones: Phubbing and nomofobia. Rev Chil Neuropsiquiatr 2017; 55(3): 205-206.

41. Aagaard J. Digital akrasia: a qualitative study of phubbing. Al Soc 2020; 35: 237-244.

42. Nazir T, Pişkin M. Phubbing: A technological invasion which connected the world but disconnected humans. Int J Indian Psychol 2016; 3(4): 68-76.

43. Davey S, Davey A, Raghav SK, et al. Predictors and consequences of "Phubbing" among adolescents and youth in India: An impact evaluation study. J Fam Community Med 2018; 25(1): 35-42.

44. Heller D, Watson D, llies R. The dynamic process of life satisfaction. J Pers 2006; 74(5): 1421-1450.

45. Pavot W, Diener E. The satisfaction with life scale and the emerging construct of life satisfaction. J Posit Psychol 2008; 3(2): 137-152.

46. Çakar FS, Karataş Z. Adolescents' self-esteem, school anger and life satisfaction as predictors of their school attachment. Education and Science 2017; 42(189): 121-136.

47. Proctor CL, Linley PA, Maltby J. Youth life satisfaction: A review of literature. J Happiness Stud 2009; 10(5): 583-630.

48. Haley WE, LaMonde LA, Han B, et al. Predictors of depression and life satisfaction among spousal caregivers in hospice: Application of a stress process model. J Palliat Med 2003; 6(2): 215-224.

49. Lee HS, Brennan PF, Daly BJ. Relationship of empathy to appraisal, depression, life satisfaction, and physical health in informal caregivers of older adults. Res Nurs Health 2001; 24(1): 44-56.

50. Mahmoud JSR, Staten RT, Hall LA, Lennie TA. The relationship among young adult college students' depression, anxiety, stress, demographics, life satisfaction, and coping styles. Issues Ment Health Nurs 2012; 33(3): 149-156. 
51. Swami V, Chamorro-Premuzic T, Sinniah D, et al. General health mediates the relationship between loneliness, life satisfaction and depression. Soc Psychiatry Psychiatr Epidemiol 2007; 42(2): 161-166.

52. Yıldz M. Üniversite öğrencilerinde duygusal zekâ yaşam doyumu ve depresyonun cinsiyet ve sınıf seviyelerine göre etkileri. Opus Uluslararası Toplum Araşırmaları Dergisi 2016; 6(11): 451-474.

53. Rachlin H. The Science of Self-Control. 3rd. Edition, Cambridge, Mass: Harvard University Press, 2009.

54. Itani 0 , Kaneita $Y$, Munezawa $T$, et al. Anger and Impulsivity among Japanese Adolescents: A Nationwide Representative Survey. J Clin Psychiatry 2016; 77(7): e860-866.

55. Fraenkel JR, Wallen NE. How to design and evaluate research. in Education 7. Edition, New York: McGraw-Hill, 2009.

56. Benet-Martínez V, John OP. Los Cinco Grandes across cultures and ethnic groups: Multitrait-multimethod analyses of the Big Five in Spanish and English. J Pers Soc Psychol 1998; 75(3): 729-750.

57. Dağlı A, Baysal N. Yaşam Doyumu Ölçeğinin Türkçe'ye uyarlanması: Geçerlik ve güvenirlik çalişmasi. Electronic Journal of Social Sciences 2016; 15(59): 1250-1262.

58. Hisli N. Beck Depresyon Ölçeği'nin bir Türk örnekleminde geçerlilik ve güvenilirliği. Psikoloji Dergisi 1988; 6: 118-122.

59. Büyüköztürk Ş, Çokluk Ö, Köklü N. Statistics for Social Sciences. 6. Baskı, Ankara: Pegem Akademi Yayınevi, 2010.

60. Büyüköztürk Ş. Sosyal Bilimler için Veri Analizi El Kitabı. 20. Baskı, Ankara Pegem Akademi, 2014.

61. Donnelly R, Renk K, Sims VK, McGuire J. The relationship between parents' and children's automatic thoughts in a college student sample. Child Psychiatry Hum Dev 2011; 42(2): 197-218.

62. Ören N, Gençdoğan B. Lise öğrencilerinin depresyon düzeylerinin bazi değişkenlere göre incelenmesi. Kastamonu Education Journal 2007; 15(1): 85-92.

63. Yavuzer $Y$, Karataş Z. Investigating the relationship between depression, negative automatic thoughts, life satisfaction and symptom interpretation in Turkish young adults. In Depression, (Ed. Dagmar Breznoscakova) (p.71-89), Croatia: Intech, 2017.

64. İskender H, Dokumacıoğlu E, Kanbay Y, Kılıç N. Üniversite öğrencilerinde sağlıklı yaşam ve depresyon puan düzeyleri ile ilgili faktörlerin belirlenmesi. ACU Sağlık Bilimleri Dergisi 2018; 9(4): 414-423.

65. Demirel C. Yetişkinlerde bağlanma stillerinin mutluluk, yaşam doyumu ve depresyon ile ilişkisinin incelenmesi. Yüksek Lisans Tezi, Işık Üniversitesi, Sosyal Bilimler Enstitüsü, İstanbul, 2018.

66. Williams K. Has the future of marriage arrived? A contemporary examination of gender, marriage, and psychological well-being. J Health Soc Behav 2003; 44(4): 470-487.

67. Simon RW. Revisiting the relationships among gender, marital status, and mental health. AJS 2002; 107(4): 1065-1096.

68. Arslantaş H, Ergin F. 50-65 Yaş arasındaki bireylerde yalnızlık, depresyon, sosyal destek ve etki eden faktörler. Türk Geriatri Dergisi 2011; 14(2): 135-144.

69. Gabilondo A, Farreras SJ, Vilagut G, et al. Epidemiology of major depressive episode in a southern European 84 country: Results from the ESEMeD-Spain Project. J Affect Disord 2010; 120: 76-85.

70. Yalvaç HD, Dikilitaş Y, Coşkun A, et al. Bir devlet hastanesine depresyon nedeniyle başvuran olgularda sosyodemografik özellikler. Güncel Psikiyatri ve Psikonörofarmakoloji 2011; 1(1): 16-20.

71. Klein DN, Kotov R, Bufferd, SJ. Personality and depression: Explanatory models and review of the evidence. Annu Rev Clin Psychol 2011; 7: 269-295.

72. Çayıırlı E. Sosyal medya kullanım özelliklerinin kişilik yapılanmaları, yaşam doyumu ve depresyon açısından incelenmesi. Yüksek Lisans Tezi, Işık Üniversitesi, Sosyal Bilimler Enstitüsü, İstanbul, 2017.

73. Bulut SS. Beş faktör kişilik özellikleri, stresle başa çıkma ve depresyon arasındaki ilişkiler: Gazi Eğitim Fakültesi örneği. Uluslararası Türkçe Edebiyat Kültür Eğitim Dergisi 2017; 6(2): 1205-1221.

74. Ivanova A, Gorbaniuk 0 , Błachnio A, et al. Mobile phone addiction, phubbing, and depression among men and women: A moderated mediation analysis. Psychiatr Q 2020; 91(3): 655-668..

75. McDaniel BT, Coyne SM. Technoference: The interference of technology in couple relationships and implications for women's personal and relational well-being. Psychol Pop Media Cult 2016; 5(1): 85-98.

76. Okwaraji FE, Aguwa EN, Shiweobi-Eze C. Life satisfaction, self esteem and depression in a sample of Nigerian Adolescents. Int Neuropsychiatr Dis J 2016; 5(3): 1-8.

77. Çivitçi A. Üniversite öğrencilerinde genel yaşam doyumu ve psikolojik intiyaçlar arasındaki ilişkiler. Ç.Ü. Sosyal Bilimler Enstitüsü Dergisi 2012; 21(2): 321-336.

78. Dolan P, Peasgood T, White M. Do we really know what make us happy? A review of the economic literatüre on the factors associated with subjective well-being. J Econ Psychol 2008; 29(1): 94-122. 


\section{Bağımlılık Dergisi - Journal of Dependence}

79. Babayiğit A, Okray Z. Relationship between depressive symptoms and life satisfaction among university students. Kibrıs Türk Psikiyatri ve Psikoloji Dergisi 2019; 1(1): 5-13.

80. Afdal A, Alizamar A, Ifdil I, Ardi Z, Sukmawati I, Zikra Z, Hariyani H. An analysis of phubbing behaviour: Preliminary research from counseling perspective. In Advances in Social Science, Education and Humanities Research 2019; Paris, Atlantis Press.

81. Kim K, Milne G, Bahl S. Smart phone addiction and mindfulness: An intergenerational comparison. Int J Pharm Healthc Mark 2018; 12(1): 25-43.

82. Kubilay-Özel N. Iş doyumu ve yaşam doyumu arasındaki ilişkinin demografik değişkenler açısından incelenmesi: Konaklama işletmelerinde bir araştırma. Yüksek Lisans Tezi. Türk Hava Kurumu Üniversitesi, Sosyal Bilimler Enstitüsü, Ankara, 2015. 